\title{
Availability of Non-lonizing Radiation Applications to Dispose Coronavirus from Foods and a Research on Creating Awareness in Protection from Coronavirus (COVID-19)
}

\section{Koronavirüsü Gıdalardan Bertaraf Etmek lçin lyonize Olmayan Radyasyon Uygulamalarının Kullanılabilirliği ve Koronavirüsten Korunma Konusunda Bilinçlendirme Araştırması (COVID-19)}

\author{
Suleyman Gokmen ${ }^{1 *}$ (D), Ismail Ors ${ }^{2}$ \\ ${ }^{1}$ Karamanoglu Mehmetbey University, Karaman, Turkey \\ ${ }^{2}$ Special Metropolitan Hospital, Konya, Turkey \\ * Corresponding author: Suleyman Gokmen E-mail: sugokmen42@hotmail.com ORCID: 0000-0002-7397-6966 \\ Received: 4 May 2020 Accepted: 30 June 2020
}

\begin{abstract}
Coronavirus (COVID-19) is one of the serious respiratory diseases known as a human pathogen. Recently, the world health organization has described this virus as a pandemic. One of the sources of transmission of this virus, which has many ways of transmission, is food. Especially foods pose a potential danger with contamination. The virus's survival even at high temperatures and for long periods led to the search for alternative applications to heat treatments applied to foods. These applications include infrared (IR), ultraviolet-C (UV-C), and microwave radiation. These applications, which are shown as an alternative to heat treatments, have recently found widespread use in foods. It was reported that applications are more effective against viral infections than heat treatments. This review study deals with methods of raising awareness of coronavirus prevention and virus removal from food.
\end{abstract}

Keywords: coronavirus, food, heat treatment, non-ionizing radiation applications

() 2020 by the authors; licensee MEDITAGEM Ltd., Turkey. This article is an open access article distributed under the terms and conditions of the Creative Commons Attribution License (http://creativecommons.org/licenses/by/4.0/). 


\section{öz}

Koronavirüs (COVID-19), insan patojeni olarak bilinen ciddi solunum yolu hastalıklarından biridir. Son zamanlarda, dünya sağlık örgütü bu virüsü bir salgın olarak tanımladı. Birçok bulaşma yoluna sahip olan bu virüsün bulaşma kaynaklarından biri gıdadır. Özellikle gıdalar kontaminasyonla potansiyel bir tehlike oluşturur. Virüsün yüksek sıcaklıklarda ve uzun süre bile hayatta kalması, gıdalara uygulanan ısıl işlemlere alternatif uygulamalar aramasına yol açtı. Bu uygulamalar arasında kızılötesi (IR), ultraviyole-C (UV-C) ve mikrodalga radyasyonu bulunur. Isıl işlemlere alternatif olarak gösterilen bu uygulamalar son zamanlarda gıdalarda yaygın olarak kullanılmaktadır. Çalışmalarda uygulamaların viral enfeksiyonlara karşı ısıl işlemlerden daha etkili olduğu bildirilmiştir. Bu derleme çalışması, koronavirüs önleme ve gıdalardan virüsün uzaklaştırılması konusunda farkındalığı artırma yöntemleri ile ilgilidir.

Anahtar kelimeler: koronavirüs, gıda, ısıl işlem, iyonlaştırıcı olmayan radyasyon uygulamaları

\section{INTRODUCTION}

Coronavirus disease (COVID-19) is a disease that causes serious respiratory conditions such as pneumonia and lung injury [1]. It is the seventh coronavirus identified as a human pathogen. Of these viruses, HKU1, NL63, OC43, and 229E can cause mild symptoms, while SARS-CoV, MERS-CoV, and SARS-CoV-2 (COVID-19) are associated with serious diseases. The path that COVID-19 takes while entering the cell is like the path followed by SARS-CoV. It enters the cell by binding strongly to the receptor binding site (RBA) on the $S$ protein and the angiotensin-converting enzyme 2 (ACE2) receptor on the cell [2].

COVID-19; it is genetically associated with the middle east respiratory syndrome (MERS). Also, its epidemiology is surprisingly similar to Severe Acute Respiratory Syndrome (SARS) [3]. It was first reported in China's Wuhan province (capital of Hubei) in December 2019 [1]. In January 2020, the first case was seen in Thailand. Later, many countries, especially Japan, South Korea, and America, started to report cases. Upon this; The World Health Organization (WHO) declared the coronavirus epidemic as an international health emergency and reported that on February 11, this disease caused by a new type of coronavirus was called coronavirus disease 2019 (COVID-19) [4]. The first case in Turkey reported on 10 March 2020 and has reached 47029 cases in a month, 1006 has led to death [5].

Although the exact route of transmission is unknown, it is thought to be transmitted by droplet. Also, the fecal-oral route is among the accused transmission routes [6]. Although initially considered to be a zoonosis factor transmitted from the seafood and livestock market in Wuhan in etiology, it has also appeared in families that have never been in Wuhan before and human-to-human transmission has been reported [7].
As the incubation period changes with long intervals such as 2-14 days, it can lead to more infections and outbreaks. COVID-19 causes symptoms such as sore throat, high fever, shortness of breath, dry cough, vomiting, headache, diarrhea, confusion, and tremor [8]. COVID-19 affects men more than 3.25: 1 . The average age is 75 . In older patients, it worsens faster than younger ones [9]. Although it is generally seen in the elderly, it can also see in children [10].

Clinical criteria, laboratory tests, nasal swab, PCR studies, Serological tests, and CT imaging methods are used for diagnosis. The positive fading of COVID-19 nucleic acid is the priority for the diagnosis of COVID-19. Patients who are not positive for nucleic ascites but are clinically suspicious should be evaluated by $\mathrm{CT}$, and when their characteristic findings are detected, their treatment should be isolated [11]. The most important thing we need to do is to prevent the virus from spreading. Capture, isolate and treat form the basis for this (Watkins J). Persons with contact history should be isolated for 14 days [8].

Healthcare workers involved in COVID-19 prevention and control are more prone to skin and mucous membraneinjuries such as acute and chronic dermatitis, secondary infections, and aggregation of underlying skin diseases. Therefore, standard consensus should be applied for protection. It is also recommended to use moisturizing products because of its highly effective barrier protective properties [12]. They must use gloves, gowns, face shields, goggles, and masks to protect the staff responsible for the treatment and patient care, especially in healthcare institutions. It should be ensured that health facilities are equipped with appropriate air conditioning and ventilation systems. It is important to place known or suspected COVID19 cases in isolation rooms. It is important to work in special autopsy rooms and using isolation methods in studies on cases known to be COVID-19 during their deaths [13]. In 
emergencies, separate areas should be created for COVID-19 patients, training of non-specialist clinicians should be provided, recent developments in treatments should be closely followed, and protocols should be established in the use of ventilators [14]. Since there are no vaccines and antiviral treatments, symptomatic treatments are applied (Watkins J). Although there is no specific treatment, broadspectrum antibiotics such as moxifloxacin, ceftriaxone, azithromycin; oseltamivir antiviral, and in some cases, it is also recommended with steroids [15].

Remdesivir, chloroquine, abidol, lopinavir/ritonavir, plasma, and antibodies are included in the treatment. Vaccination studies and stem cell therapy studies are ongoing [16]. This infection, which has been effective in more than 170 countries all over the world for more than four and a half months, continues to affect many areas economically and psychologically [17-21].

One of the ways of transmission of coronavirus is also food. Food can be transmitted both in production and at every stage of storage and marketing. For these reasons, it is essential to protect and ensure food safety. For this, necessary measures should be taken in the food industry.

Precautions to be taken in food-producing establishments;

1. Providing hygiene and sanitation in washbasins,

2. Taking one transporter of the symptoms of COVID-19, to the nearest health institution,

3. Used clothes are constantly cleaned and disinfected,

4. The routine washing of work clothes at the appropriate temperature,

5. Use of masks and gloves in dining halls,

6. Ensuring social isolation,

7. Termination of contact,

8. Prevention of collective social activities,

9. Working with the least number of workers considering production planning,

10. Washing the dishes at the appropriate temperature without the opportunity for contamination,

11. Disinfectant and mask should be found in service vehicles,

12. When suppliers come, body temperatures should be checked with a fever meter,

13. Risk assessments should be constantly strengthened,

14. Living areas in the business should be routinely disinfected.

Contamination can consist of the hands, sneezing, and coughing of labors responsible for the manufacturing, packaging, and storing of food, and according to the WHO's

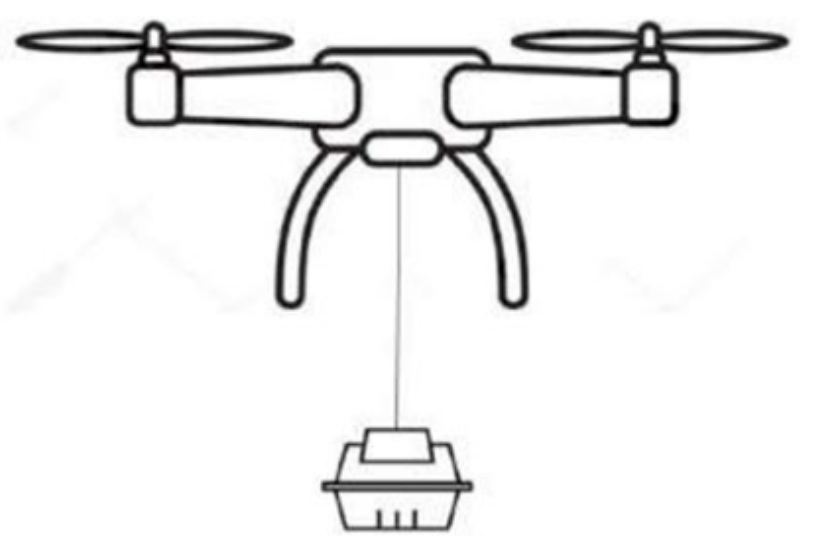

Figure 1. Drone-based system for non-contact food delivery

findings, consumption of contaminated raw material and unclean food can induce human disease [22-23]. Modern or traditional applications for inactivation of viruses in foods were given below.

1. High-temperature treatments should be at minimum $70^{\circ} \mathrm{C}$ because coronavirus can be active at $-20^{\circ} \mathrm{C}$ or less for 2 years.

2. The virus can be inactivated by ionizing radiation at doses from 2.7 to $3.0 \mathrm{kGy}$

3. The virus can be inactivated by non-ionized radiation such as ultraviolet-c (uv-c), infrared, and microwave especially uv-c applications for surface sterilization such as egg, fruits, and vegetable surface.

4. High-pressure applications (300-400 MPa, and 5- $22^{\circ} \mathrm{C}$ temperatures for 5 minutes) such as fish, fruit juice, and pre-cooked meat products.

5. Chlorine, chlorine dioxide ozone gas, sodium, and calcium hypochlorite for 1 minute such as water or food packaging.

6. In the process of the epidemic, the need for food increases due to quarantine applications [24]. For this reason, drones transport systems are developed to maintain contact and social distance during the marketing and retail sale of foods. The system developed for this purpose is given in Figure 1.

Moreover, the food supply chain is a link that connects a food system with the consumer's dinner table, including processes such as producing, storage, packaging, and distribution [24-25] (Figure 2).

Besides that, recommendations to consumers for protection from the virus were given in Table 1. 


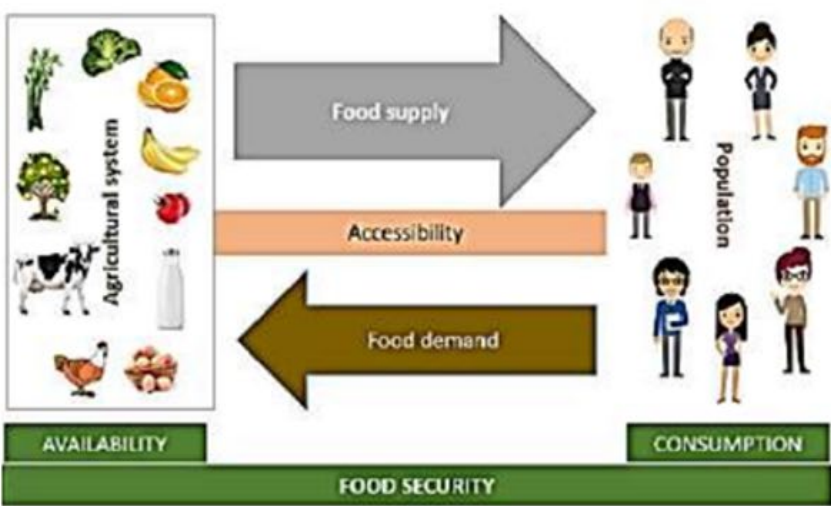

(a)

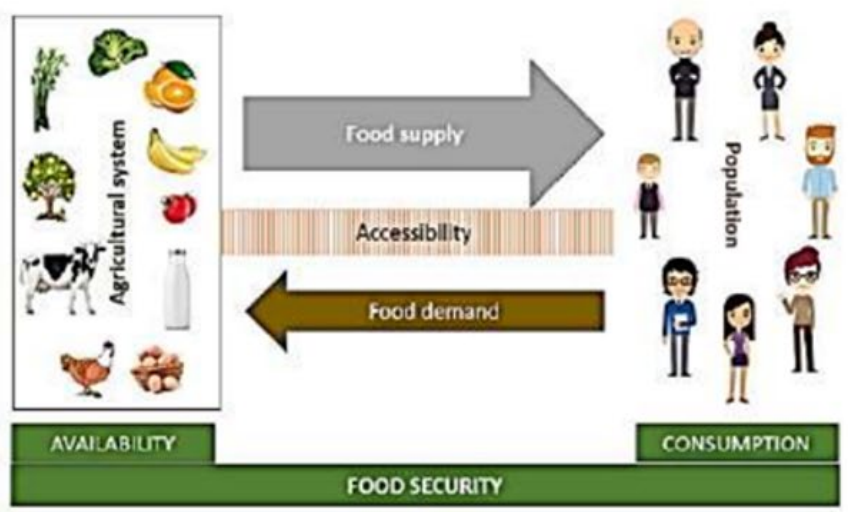

(b)

Figure 2. Food security system (a) without COVID-19 and (b) with COVID-19. Both supply and demand have been affected, although a greater effect on demand, due to the passability restrictions that affect accessibility. Availability and consumption remain almost stable. The agricultural system includes producers, raw materials, agricultural machinery and inputs, processing plants, and farm and industrialized food. Consumption includes people and different marketing systems.

Table 1. Recommendations to consumers for protection from viruses [26-36]

\begin{tabular}{|l|l|l|}
\hline Material & Application & Precautions \\
\hline Food packages & $\begin{array}{l}\text { When removing food packages from store } \\
\text { shelves }\end{array}$ & $\begin{array}{l}\text { You should use latex gloves. } \\
\text { Wash the packages which are purchased from the market } \\
\text { with water and disinfectants at home }\end{array}$ \\
\hline Bread & Completely safe & $\begin{array}{l}\text { The virus may be contaminated by bread crumbs and } \\
\text { knives. Therefore, it should be avoided slicing the bread. } \\
\text { Moreover, pre-heat traditional and industrial bread by } \\
\text { microwave or traditional method before consumption. }\end{array}$ \\
\hline Raw milk and pasteurized milk & Should be boiled before using & should do not use traditional dairy products \\
\hline Vegetables and fruits & After washing, transfer to the refrigerator & Should be washed \\
\hline Raw and partially cooked foods & Cross-contamination should not be. & It must be stored separately. \\
\hline The nuts & Should be roast at home & Should be not consumed as raw \\
\hline The fruits & Can be dried by microwave & $\begin{array}{l}\text { Should be washed which are purchased from the market } \\
\text { before consumption }\end{array}$ \\
\hline The kitchen & Regularly clean and disinfect & Contamination \\
\hline Probiotic foods & Should be consumed regularly & $\begin{array}{l}\text { May bind directly to the virus, inhibit virus attachment to } \\
\text { the host cell, and improving the immune system. }\end{array}$ \\
\hline
\end{tabular}

Another stage of the food production chain is the application of heat treatment to foods. Studies have reported that COVID-19 remains alive at high temperatures for a long time. Therefore, it should be investigated in different applications as an alternative to heat treatment. One of these applications is non-ionizing radiation. This radiation does not pose any health risks and even has an effective inactivation mechanism against the virus. These radiations include microwave, infrared and UV-C applications. Microwave applications are now used for purposes such as food preservation, especially in many heat treatments. Microwave can be applied as a pretreatment at processes such as thawing, drying, cooking, and boiling. In the food industry, the IR heating application is applied in the processes of foods such as drying, thawing, pasteurization and sterilization, roasting, peeling, cooking, boiling, etc [37].
It should be remembered that the radiation used in microwave and IR applications is electromagnetic radiation and that the harmful effect of this radiation on both food and human health is minimized. Another radiation application is UV-C. It is used in surface sterilization due to its anti-microbial effect. Also, it is easily used in fruit juices in the application known as cold sterilization in the food industry. In studies conducted, it is reported that UV-C application is effectively eliminated COVID-19. The aforementioned radiation has advantages and disadvantages. Therefore, radiation can be combined by the food material.

\section{CONCLUSIONS}

In this review study, the methods to be used for the disposal of COVID-19 from foods have been examined. Due to the 
outbreak, the significant change in lifestyle, the increase in working hours, and the ever-decreasing availability of time to cook led to the inevitable triumph of supermarkets and discount stores. Therefore, to prevent the epidemic, food safety needs to be sustainable to balance the increasing supply and demand. To prevent the spread of the foodborne virus;

- Prevention of contact by state quarantine practices and some restrictions,

Use of drones to cut off contact at the supermarkets,

- Non-ionizing radiation applications in foods: Non-ionizing radiation applications have become popular in the food industry in recent years. The most important of these are UV infrared and microwave applications. Especially these processes are widely used in important heat treatment applications such as drying, cooking, heating, surface sterilization in foods. Among these processes, UV application is an application known as cold sterilization application besides being used as an alternative process to pasteurization, especially in providing surface sterilization. This application is used as an alternative to heating treatment as well as to kill microorganisms like bacteria viruses. Therefore, COVID-19 can be used effectively as an alternative to heat treatment in outbreaks. It can also be applied as a final treatment to eliminate contamination from any source during the production process. Another application is infrared radiation. This radiation can be used especially in short wavelength and high-power food processes. Thus, both heat treatment and sterilization process can be provided in foods. Microwave, on the other hand, can be used for pre-heating of foods, defrosting, and sudden heating. Thus, processing time can be shortened. When the applications such as infrared, UV, and microwave are used in combination, it will be supplied effective sterilization in foods,

- The application of these radiations in the food industry to prevent epidemic situations can be easily applied in preventing the transportation of the epidemic with food, and also preventing the transport of other than food with personnel and other carriers.

It was concluded that this virus, which is likely to be transmitted in foods non-ionized radiation applications compared to heat treatment applications such as pasteurization, may prevent the formation of more resistant species to environmental conditions by mutation.

\section{DECLARATION OF CONFLICT OF INTEREST}

The authors received no financial support for the research and/or authorship of this article. There is no conflict of interest.

\section{REFERENCES}

1. Dae-Gyun A, Hye-Jin S, Mi-Hwa K, Sunhee L, Hae-Soo K, Jinjong M, Bum-Tae K, Seong-Jun K. Current Status of Epidemiology, Diagnosis, Therapeutics, and Vaccines for Novel Coronavirus Disease 2019 (COVID-19). J Microbiol Biotechnol 2020; 30: 313-24. (doi: 10.4014/jmb.2003.03011).

2. Feyzioglu B. SARS-CoV-2 Kökeni. J Biotechnol and Strategic Health Res 2020;1: 1-9. (doi: 10.34084/bshr.712379).

3. Kannan S, Shaik Syed AP, Sheeza A, Hemalatha K. COVID19 (Novel Coronavirus 2019)-recent trends. Euro Review for Med and Pharm Sci 2020; 24: 2006-11.

4. Ugras D, Kina HM, Zkan S, Illhan MN. COVID-19 Epidemiyolojisi: Pandemiden $\mathrm{Ne}$ Ögrendik [Epidemiology of COVID-19: What We Learned from Pandemia]. J Biotechnol and Strategic Health Res. 2020; 1: 29-36. Turkish. (doi: 10.34084/bshr.715153).

5. Hasoksuz M, Kilic S, Sarac F. Coronaviruses and SARSCOV-2. Turk J Med Sci 2020; 50: 549-56. (doi: 10.3906/sag2004-127).

6. Ciotti $M$, Angeletti $S$, Minieri $M$, Giovannetti $M$, Benvenuto D, Pascarella S, Sagnelli C, Bianchi $M$, Bernardini S, Ciccozzi M. COVID-19 Outbreak: An Overview. Chemotherapy 2020: 1-9. (doi: 10.1159/000507423).

7. Carlos WG, Dela Cruz CS, Cao B, Pasnick S, Jamil S. Novel Wuhan (2019-nCoV) Coronavirus. Am J Respir Crit Care Med. 2020; 15: 7-8. (doi: 10.1164/rccm.2014P7).

8. Ozma MA, Maroufi P, Khodadadi E, Kose S, Esposito I, Ganbarov K, Dao S, Esposito S, Dal T, Zeinalzadeh E, Kafil HS. Clinical manifestation, diagnosis, prevention and control of SARS-CoV-2 (COVID-19) during the outbreak period. Infez Med 2020; 28: 153-65.

9. Wang W, Tang J, Wei F. Updated understanding of the outbreak of 2019 novel coronavirus (2019-nCoV) in Wuhan, China. J Med Virol. 2020; 1: 15-21. (doi: 10.1002/jmv.25689). 
10. Liu W, Zhang Q, Chen J, Xiang R, Song H, Shu S, et al. Detection of Covid-19 in Children in Early January 2020 in Wuhan, China. N Engl J Med 2020; 14: 1370-71. (doi: 10.1056/NEJMc2003717).

11. Uludag O. Koronavirüs enfeksiyonları ve yeni düşman: COVID-19 [Coronavirus infections and new enemy: COVID-19]. Adıyaman Üniversitesi Sağlık Bilimleri Dergisi- Adıyaman University Journal of Health Sciences 2020; 6: 118-27. Turkish. (doi: 10.30569/adiyamansaglik.716011).

12. Yan $Y$, Chen $H$, Chen $L$, Cheng B, Diao $P$, Dong $L$, et al. Consensus of Chinese experts on protection of skin and mucous membrane barrier for health-care workers fighting against coronavirus disease 2019. Dermatol Ther. 2020; 1: 13310. (doi: 10.1111/dth.13310).

13. Çetintepe SP, İlhan MN. COVID-19 Salgınında Sağlık Çalışanlarında Risk Azaltılması. J Biotechnol and Strategic Health Res. 2020; 1: 50-4. (doi: 10.34084/bshr.712539).

14. Rudnicka L, Gupta M, Kassir M, Jafferany M, Lotti T, Sadoughifar R, Goldust M. Priorities for global health community in COVID-19 pandemic. Dermatol Ther. 2020; 1: 13361. (doi: 10.1111/dth.13361).

15. Giwa AL, Desai A. Novel coronavirus COVID-19: an overview for emergency clinicians. Emerg Med Pract. 2020; 22: 1-21.

16. Zhu S, Guo X, Geary K, Zhang D. Emerging Therapeutic Strategies for COVID-19 patients. Discoveries (Craiova). 2020; 8: 15190-92. (doi: 10.15190/d.2020.2).

17. Ankarali H, Ankarali S, Erarslan N. COVID-19, SARS-CoV2, Enfeksiyonu: Güncel Epidemiyolojik Analiz ve Hastalık Seyrinin Modellemesi [COVID-19, SARS-CoV2, Infection: Current Epidemiological Analysis and Modeling of the Disease Course]. Anatolian Clinic J of Med Sci 2020; 25: 122. Turkish. (doi: 10.21673/anadoluklin.707038).

18. Kilinc E, Baranoglu Kilinc Y. Mast Cell Stabilizers as a Supportive Therapy Can Contribute to Alleviate Fatal Inflammatory Responses and Severity of Pulmonary Complications in COVID-19 Infection. Anadolu Kliniği Tıp Bilimleri Dergisi - Anadolu Clinic Journal of Medical Sciences 2020;25: 111-19. (doi: 10.21673/anadoluklin.720116).
19. Yılmaz D. Diş Hekimliği ve Dental Klinikler Yönünden COVID-19 Enfeksiyonu [COVID-19 Infection in Terms of Dentistry and Dental Clinics]. J Biotechnol and Strategic Health Res 2020; 1: 22-8. Turkish. (doi: 10.34084/bshr.712302).

20. Bulut C, Kato Y. Epidemiology of COVID-19. Turk J Med Sci 2020; 50: 563-70. (doi: 10.3906/sag-2004-172).

21. Watkins J. Preventing a covid-19 pandemic. BMJ 2020; 28: 368-81. (doi: 10.1136/bmj.m810).

22. Deaton B, Deaton J, Brady J. Food security and Canada's agricultural system challenged by COVID-19. Canadian Journal of Agricultural Economics/Revue canadienne d'agroeconomie 2020;1: 10-5. (doi: 10.1111/cjag.12227).

23. Siche R. What is the impact of COVID-19 disease on agriculture? Scientia Agropecuaria 2020;11: 3-6. (doi: 10.17268/sci.agropecu.2020.01.00).

24. WHO. Coronavirus disease 2019 (COVID-19): situation report-63. Available at: https://www.who.int/docs/ defaultsource/coronaviruse/situation-reports (Accessed: 1 May 2020).

25. WHO. Coronavirus disease 2019 (COVID-19): situation report. Available at: https://www.who.int/docs/default source/coronaviruse/situation-reports (Accessed: 1 May 2020).

26. Hirneisen KA, Black EP, Cascarino JL. Viral inactivation in foods: a review of traditional and novel food- processing technologies. Comprehen Rev Food Sci Food Safe 2010; 9: 3-20. (doi: 10.1111/j.1541-4337.2009.00092.x).

27. Bidawid S, Farber J, Sattar S. Inactivation of hepatitis A virus (HAV) in fruits and vegetables by gamma irradiation. Int J Food Microb 2000; 57: 91- 7. (doi: 10.1016/S0168-1605(00)00235-X).

28. Grove SF, Lee A, Lewis T. Inactivation of foodborne viruses of significance by high pressure and other processes. J Food Protect 2006; 69: 957-68. (doi: 10.4315/0362-028X-69.4.957).

29. Kingsley $\mathrm{DH}$. High pressure processing and its application to the challenge of virus-contaminated foods. Food Environ Virolog 2013; 5: 1-12. (doi: 10.1007/s12560-012-9094-9).

30. Hudson JB, Sharma M, Vimalanathan S. Development of a practical method for using ozone gas as a virus decontaminating agent. Ozone: Sci Engin 2009; 31: 216 23. (doi: 10.1080/01919510902747969). 
31. Wang X-W, Li J-S, Jin M. Study on the resistance of severe acute respiratory syndromeassociated coronavirus. J Virolog Method 2005; 126: 171-7. (doi: 10.1016/j.jviromet.2005.02.005).

32. Kampf G, Todt D, Pfaender S. Persistence of coronaviruses on inanimate surfaces and its inactivation with biocidal agents. J Hospital Infect 2020; 104: 246-51. (doi: 10.1016/j.jhin.2020.01.022).

33. WHO. Novel Coronavirus (2019-nCoV): situation report-3. Available at: https://www.who.int/docs/defaultsource/ coronaviruse/situation-reports (Accessed: 1 May 2020).

34. Bertrand I, Schijven J, Sánchez G. The impact of temperature on the inactivation of enteric viruses in food and water: a review. J Appl Microbiol 2012; 112: 1059-74. (doi: 10.1111/j.1365-2672.2012.05267.x).
35. Ahmadiara E. Possibility of fecal-oral transmission of novel coronavirus (SARS-CoV-2) via consumption of contaminated foods of animal origin: A hypothesis. J Food Qual \& Hazard Control 2020; 7: 1-3. (doi: 10.18502/jfqhc.7.1.2445).

36. Restrepo M. Health Status and the Role of Nutrition on SARS-CoV/Covid-19. Available at: https://nakedfood magazine.com/health-status-covid-19/ (Available at: 1 May 2020).

37. Gokmen S, Sayaslan A, Caglar A. Mantıda Farklı Kurutma Yöntemlerinin Hidroksimetil Furfural (HMF) Oluşumu ve Duyusal Kalite Üzerine Etkileri [Effects of Different Drying Methods in Mantı on Hydroxymethyl Furfural (HMF) Formation and Sensory Quality]. Cumhuriyet Üniversitesi Fen-Edebiyat Fakültesi Fen Bilimleri Dergisi - Cumhuriyet University Faculty of Arts and Sciences Journal of Science 2016; 37: 176-86. Turkish. (doi: 10.17776/csj.42816). 